\title{
German cancer centre criticized
}

Report urges major changes in constitution

Sweeping changes at the Deutsches Krebsforschungzentrum (DKFZ) in Heidelberg have been recommended by the international commission appointed by the German Minister for Science and Technology. The proposed changes would invest the director of DKFZ with executive power, the lack of which caused the resignation of Professor Hans Neurath last year (see Nature 293,252; 1981).

The report, published last week by the ministry, is highly critical of the overall performance of DKFZ in basic research. Although acclaiming the quality of research by some investigators in the centre's eight institutes, particularly those of cell biology, immunology and virology, the report says that in a large number of the institute's 39 divisions, the research work is merely reliable and unimaginative. And the output of a number of scientists has amounted to little more than one unremarkable paper a year for the past decade: Overall "this does not indicate that the quality of research commissioned in DKFZ is in any way outstanding".

The centre is also criticized for its lack of collaborative ventures and its failure to take a lead in arranging multi-centre clinical trials. The commission considers that the largest cancer centre in Western Europe, employing more than 1,000 staff at an annual cost of DM90 million ( $£ 20$ million), should do better.

Two main factors are said to account for the mediocre performance of DKFZ. The first is lack of effective external peer review. The second is that the constitution of the centre is such that the director does not necessarily have the power to bring about changes. "His proposals may be blocked or intolerably delayed and his position can be undermined by other proposals ... from the Scientific Council" (a committee made up of the heads of institutes and an equal number of elected staff members). It was intolerable difficulties of this kind that Professor Neurath had "bravely attempted to overcome", says the report.

The resolution of this problem, says the commission, is of paramount importance to the future of DKFZ. It proposes that DKFZ's director (officially chairman of the executive board) should also serve as chairman of the Science Council. In this way the director could no longer be subordinate to his staff and could assume authoritative direction of the centre.

In the commission's view, the Science Council would still be a powerful advisory group whose majority view its chairman, the director, could ignore only at his peril (his is the only senior post without tenure).

On peer review, the commission says there is no adequate system to ensure that resources are wisely distributed among a staff most of whom have unlimited tenure. Some form of peer review has periodically been carried out by the centre's Science Advisory Council (Wissenschaftliche Beirat) but the council is not required by the constitution to conduct such reviews, is too small to perform the job adequately and is open to influence from the staff.

The commission proposes that the Science Advisory Council be replaced by a committee of eight independent scientists who would be responsible for arranging regular external peer reviews of all institutes and divisions of DKFZ. The same independent scientists would also fill the eight places for scientists on the Kuratorium. No longer would three of these posts be filled by elected members of

\section{Yale says no to a $\$ 33,000$ grant}

\section{Washington}

Yale University last week reluctantly bit one of the hands that feed it, and declined a $\$ 33,000$ grant offered by the National Science Foundation for one year beginning on 1 May. By this unprecedented act, the university also gave renewed publicity to the fact that one of its faculty, mathematics professor Dr Serge Lang, strongly objects to the US government's requirement that recipients of federal research grants should produce detailed reports of the amount of time they spend working on federally supported projects.

Dr Lang described himself on the telephone last week as one "who knows more about A21 than anybody else". The reference is to the much disputed circular A21, issued by the Bureau of the Budget (now the Office of Management and Budget, OMB) more than twenty years ago. Yale's refusal of the grant, the renewal for a third year of its support for Dr Lang's project "Number theory and elliptic curves", is due to his refusal to accept the reporting requirements.

Dr Lang also said last week that his objections to "effort reporting" were unlikely to be met by the revision of A21 now being considered by OMB, which are substantially those agreed last year between OMB and groups such as the American Association of Universities and the Council of Scientific Society Presidents.

Since the publication of the proposed revision in the Federal Register on 7 January, there has been a steady flood of protests from academic scientists that even the proposed revisions do not meet the objection that it is meaningless to attempt
DKFZ. The commission considers that staff members have no place on the executive board of the institute that employs them whereas the director, who is not a voting member of the Kuratorium, should be on the board .

It is on the question of "worker participation" that there is bound to be political opposition to change. Staff representation on the Kuratorium began in 1975 , when it was being widely adopted in both public and private concerns throughout Germany. Dr Wolfgang Finke, now chairman of the Kuratorium, would prefer to see it retained on the grounds that the presence of staff scientists on the Kuratorium has been a useful channel of information between the staff and the trustees. If there is a problem, he feels, it arises from the individuals concerned, not the principle.

Apart from that point, Dr Finke believes that the Kuratorium should give serious consideration to all of the commission's

to distinguish between time spent on teaching and time spent on research. As published, the revision of A21 would do away with the requirement for a detailed account of the time spent on various activities by faculty members supported partly by federal funds. Instead, three alternative methods of accounting for effort devoted to federal projects are proposed, one of which would allow of a certifying signature by "a person having direct knowledge of the work" and not by the faculty member as such.

In the draft revision, however, OMB has not conceded the principle urged by many academic scientists that there are circumstances, research by graduate students for example, in which it is literally meaningless to seek to distinguish between research and teaching. Opponents of OMB's accounting ambitions are able with relish to quote on this point from the report of a task force in 1968 under Cecil E. Goode, then an official of the Bureau of the Budget.

Part of the reason why A21 has become a source of contention in the past three years is that government auditors have been seeking to use it as a means of quantifying (and presumably limiting) the indirect costs added to research grants as compensation for the administrative work carried out centrally by a university. Yale was not impelled to decline the first two instalments of Dr Lang's three-year grant because of a dispensation which expired at the beginning of this year.

Under the terms of the grant offered, Yale would have been paid two-ninths of Dr Lang's salary by way of compensation for work done during the long vacation. 
recommendations. He will no longer be its chairman when the Kuratorium comes to consider the future of DKFZ on 21 June because, from 1 May responsibility for the centre will be shifted as part of a reshuffle of responsibilities in the ministry. It is likely that the new chairman will be Dr Güentsch.

Professor Hans Neurath, now back in the University of Washington, Seattle, also welcomes the report, describing it as "excellent, clear and succinct".

Reaction to the report at DKFZ is hard to gauge, but inevitably mixed.

Only after the 21 June meeting of the Kuratorium will it be known which of the commission's proposals will be adopted. One problem is that since Professor Neurath's resignation, DKFZ has been without a real director, although Professor Otto Westphal was appointed acting director from 1 March until the end of 1982. Another is that there is almost certain to be strong resistance to many of the proposals from within the centre. And it does not help that the politicization of the centre's difficulties comes at a time when the German government has matters of far greater importance on its plate - survival for example.

Thus, whereas the commission recommends that proper peer review of DKFZ starts without delay, with at least three institutes to be reviewed by the end of the year, there is a good chance that the peers will need topcoats rather than safari suits by the time they descend upon Heidelberg.

Peter Newmark

\section{Europe's nuclear power}

\section{Border incidents} Brussels

A bizarre mixture of Molotov cocktails and red and yellow balloons was released at a demonstration on 27 March when Belgian environmentalists protested at the continuing construction of four French nuclear power stations at Chooz, close to the Belgian border. Protests against the Chooz reactors are now a regular part of Belgian life. Some weeks ago, the Belgian Embassy in Paris was occupied by two Belgian senators belonging to the environmental party, and demonstrations on the border are now promised on the last Saturday of each month.

While there is no sign that the protests will influence the French government's determination to press ahead with the four $1,300 \mathrm{MW}$ reactors to be built on the Meuse at Chooz, they may affect the Belgian government's willingness to participate in the project. Given the prospect that Belgium will have to rely on nuclear power for half of its electricity production by 1985, the government must either sanction the nuclear power construction in Belgian or join in the Chooz project.

For a time, the government sought to obtain electricity and to counter the protests by linking participation at $\mathrm{ChOOz}$ with the stipulation that the French reactors should be built to Belgian safety standards. This suggestion has, however, been rejected by the French on the grounds that construction costs would be increased.

The issue has thus been invested with national pride. The Belgian government is being told, most vociferously by the Flemish-speaking population near the border, that it has allowed itself to be bullied by its larger neighbour. France, on the other hand, cannot admit that its own safety standards for reactors are inadequate simply because the Belgian standards are more stringent. France has also declined to reveal details of the reactors to be built at Chooz beginning in December, and to reveal plans for the discharge of some low-level waste into the Meuse.

There is a chance that the European Commission may be able to help. The revision of Article 37 of the Euratom Treaty soon to be adopted would require France to seek approval for its plans for radioactive waste disposal six months before construction at $\mathrm{Chooz}$ begins. So far, however, there is no sign that France is prepared to let the commission interfere or to engage in consultations with Belgium.

The Belgian government is in any case itself divided over the country's energy plans. The energy minister, Mr Etienne Knoops, is anxious that Belgium should have more nuclear power stations and keen on participation at Chooz. $\mathrm{He}$ is opposed by the science and budget minister, $\mathrm{Mr}$ Philip Maystadt, who wants the decision on Chooz put off until the parliamentary debate arranged for the end of May - after the 16 April deadline for a decision on participation will have passed.

In the end, Maystadt's arguments are likely to prevail. Belgian utility companies argue that it would be more sensible to invest in a Belgian project than in Chooz, especially because it is now estimated that Belgium will need to build thirteen 1,300 MW reactors by the year 2020 . In any case, the cost of electricity from the Chooz plant quoted by the French is unpalatably high.

Jasper Becker

Environmentalists are also on the move in France - on foot, in fact, between the site of the near-complete French fast breeder reactor, Superphenix, in the south of France, to Paris, where they hope to meet President Mitterrand on 18 April to protest against fast breeder development. A hundred demonstrators gathered on Sunday near Superphenix in the march, which has begun peacefully. This is in marked contrast to the rocket attack on Superphénix last summer, and the violent demonstrations of 1977 in which one demonstrator died. Brice Lalond, national secretary of the French Friends of the Earth, addressed the marchers. "Nothing has changed since 10 May", he said, referring to the election of Mitterrand as President of France and his socialist government.
United States astronomy

\section{High priorities}

Apparently unabashed by the austerity now rife in Washington, the long-awaited Field report on astronomy and astrophysics in the 1980 s will include a $\$ 1,900$ million (at 1980 prices) shopping-list, mostly for new equipment. A draft of the report (to be published next month) says that these plans would require that the astronomy budget of the National Science Foundation (NSF) in the 1980s should be 30 per cent greater in real terms than in the 1970 s.

The report has been prepared by the Astronomy Survey Committee under the chairmanship of the director of the Harvard-Smithsonian Center for Astrophysics, George Field. The committee was set up in 1978 by the National Academy of Sciences (NAS) to assign priorities to a wide range of astronomical projects based on the ground or in Earth orbit, but excluding planetary missions and deep-space probes.

\begin{tabular}{|c|c|}
\hline Field report recommendatio & S millio \\
\hline $\begin{array}{l}\text { Major new programmes, in order of pric } \\
\text { 1. Advanced X-ray Astronomy }\end{array}$ & \\
\hline Facility (AXAF) & 500 \\
\hline 2. Very Long Base-line (VLB) Array & 50 \\
\hline 3. New Techn & 100 \\
\hline 4. Large Deplo & 300 \\
\hline
\end{tabular}

Modest new programmes, in rough order of priority

1. Augmentation of Explorer satellite programme

2. Far UV spectrograph in space

3. Space VLB antenna

4. Optical/IR telescopes $(2.5 \mathrm{~m})$

5. Advanced Solar Observatory in space

6. Cosmic ray experiments

7. Search for Extraterrestrial Intelligence

200
150
60
20
200
100
20

Small new programmes

$10 \mathrm{~m}$ submillimetre-wave radio antenna

Other important programmes

Spatial interferometer for mid-IR

High precision optical astrometry programme

Temporary programme to maintain astronomical expertise at

universities

Total expenditure over decade on new project Total expenditure on "prerequisites" (theory, data analysis, etc.) Grand total $\$ 1,910$ million $\$ 1,910$ 20

In its review of astronomical problems and the best ways of tackling them, the report assumes the existence of such shuttle-dependent projects as the Space Telescope, the Gamma-Ray Observatory, the Shuttle Infrared Telescope Facility, the Solar Optical Telescope and the groundbased 25-metre millimetre-wave radiotelescope, all but the last of which appear to have survived in the US Administration's budget for 1983 .

For the $1980 \mathrm{~s}$, the committee recommends that the highest priorities should be given to the Advanced X-ray Astrophysics Facility (AXAF) satellite, a Very Long Baseline (VLB) array of radiotelescopes, a 